\title{
Paracoccus chinensis sp. nov., isolated from sediment of a reservoir
}

\author{
Hai-Feng Li, Jian-Hang Qu, Jin-Shui Yang, Zhi-Jian Li and Hong-Li Yuan
}

Correspondence

Hong-Li Yuan

hlyuan@cau.edu.cn
State Key Lab for Agrobiotechnology, College of Biological Sciences, Key Laboratory of Agro-Microbial Resource and Utilization, Ministry of Agriculture, China Agricultural University, Beijing 100193, PR China

A Gram-negative, short ovoid- to coccus-shaped, aerobic, motile, non-spore-forming bacterium (designated strain $\mathrm{KS}-11^{\top}$ ) was isolated from sediment of the eutrophic Guanting reservoir in Beijing, China. Colonies grown on R2A agar plates were circular, convex and colourless to orange. The strain grew in the presence of up to $1 \% \mathrm{NaCl}$ (optimum, $0 \% \mathrm{NaCl}$ ). Growth occurred at $25-40{ }^{\circ} \mathrm{C}$ (optimum, $28-37{ }^{\circ} \mathrm{C}$ ) and at $\mathrm{pH} 6.0-9.5$ (optimum, $\mathrm{pH} 7.5-9.0$ ). On the basis of $16 \mathrm{~S}$ rRNA gene sequence similarity, strain $\mathrm{KS}-11^{\top}$ was shown to belong to the class Alphaproteobacteria, being closely related to Paracoccus marinus (96.9\% 16S rRNA gene sequence similarity), followed by Paracoccus koreensis (96.8\%), Paracoccus solventivorans (96.8\%), Paracoccus alkenifer (96.2\%) and Paracoccus kocurii (95.8\%). The major fatty acids of strain $\mathrm{KS}-11^{\top}$ were summed feature $7\left(\mathrm{C}_{18: 1} \omega 7 \mathrm{c} / \omega 9 \mathrm{t} / \omega 12 t\right)(83.8 \%)$ and $\mathrm{C}_{18: 0}(6.5 \%)$ and the $\mathrm{G}+\mathrm{C}$ content of the genomic DNA was $69.0 \mathrm{~mol} \%$. Based on comparative analysis of physiological and chemotaxonomic data, it is proposed that strain $\mathrm{KS}-11^{\top}$ represents a novel species of the genus Paracoccus, named Paracoccus chinensis sp. nov. The type strain is KS $-11^{\top}\left(=\right.$ CGMCC $1.7655^{\top}=$ NBRC $\left.104937^{\top}\right)$.
The Guanting reservoir lies in the north-west of Beijing, China and has been eutrophic for several decades. Several novel bacterial strains have been isolated from the reservoir sediment (Qu \& Yuan, 2008a; Qu et al., 2008b). One of the isolates, designated strain $\mathrm{KS}-11^{\mathrm{T}}$, was found to be a member of the genus Paracoccus in the Alphaproteobacteria according to the $16 \mathrm{~S}$ rRNA gene sequence phylogenetic analysis.

The genus Paracoccus was first reported by Davis et al. (1969). To date, the genus is composed of more than 20 species with validly published names. The Gram-negative, catalase- and oxidase-positive, coccus or short-rod members of this genus show a variety of metabolic properties. One species is able to grow methylotrophically with methyl compounds such as methylamine or $N, N$-dimethylformamide (Urakami et al., 1990). Another species can oxidize reduced sulfur compounds (Rainey et al., 1999), whereas some strains are able to reduce nitrate to $\mathrm{N}_{2}$ under anaerobic conditions (Siller et al., 1996). Paracoccus koreensis (La et al., 2005), Paracoccus homiensis (Kim et al., 2006), Paracoccus marinus (Khan et al., 2008) and Paracoccus halophilus (Liu et al., 2008) were described recently.

The GenBank/EMBL/DDBJ accession number for the 16S rRNA gene sequence of strain $\mathrm{KS}-11^{\top}$ is EU660389.

Minimum-evolution and maximum-parsimony phylogenetic trees based on the 16S rRNA gene sequences are available as supplementary material with the online version of this paper.
Strain KS- $11^{\mathrm{T}}$ was isolated from surface sediment of the Guanting reservoir. The samples were suspended and serially diluted in $50 \mathrm{mM}$ phosphate buffer $(\mathrm{pH} 7.0)$ and spread on R2A agar plates (containing, $\mathrm{l}^{-1}$ distilled water: $0.5 \mathrm{~g}$ glucose, $0.5 \mathrm{~g}$ soluble starch, $0.5 \mathrm{~g}$ casein hydrolysate, $0.5 \mathrm{~g}$ yeast extract, $0.5 \mathrm{~g}$ peptone, $0.05 \mathrm{~g} \mathrm{MgSO}_{4} \cdot 7 \mathrm{H}_{2} \mathrm{O}$, $0.3 \mathrm{~g} \mathrm{KH}_{2} \mathrm{PO}_{4}$ and $16 \mathrm{~g}$ agar, with the $\mathrm{pH}$ adjusted to 7.2 prior to autoclaving). After incubation at $28{ }^{\circ} \mathrm{C}$ for 3 weeks, well-separated colonies were picked randomly and purified by subculture on new plates. This procedure was performed several times. Strain $\mathrm{KS}-11^{\mathrm{T}}$ comprised one of these colonies and was cultured routinely on R2A agar plates and maintained as a glycerol suspension $(20 \%$, v/v) at $-80{ }^{\circ} \mathrm{C}$. The temperature range and optimum for growth were determined at $4,20,28,37$ and $45{ }^{\circ} \mathrm{C}$ on R2A agar plates for 20 days. The $\mathrm{pH}$ range and optimum for growth were examined by incubating cells in R2A broth at $\mathrm{pH} 5.0-10.0$ (at $0.5 \mathrm{pH}$ unit intervals), with the $\mathrm{pH}$ adjusted using $1 \mathrm{M} \mathrm{HCl}$ or $1 \mathrm{M} \mathrm{NaOH}$. Tolerance to salinity was investigated in R2A broth supplemented with $0,0.5,1,2,3,4,5,10$ and $15 \%(\mathrm{w} / \mathrm{v}) \mathrm{NaCl}$.

Cell morphology was observed under an Olympus light microscope at $\times 1000$. Gram-staining was determined using $24 \mathrm{~h}$ cultures on R2A agar plates (Skerman, 1967). Motility was determined using the hanging drop technique and tested by using stab cultures in semisolid R2A medium. Hydrolysis of carboxymethylcellulose, starch and gelatin, lecithinase activity, lipase activity (Tween 80), 
production of indole and hydrogen sulfide, activities of arginine dihydrolase and urease, and reduction of nitrate and nitrite were all investigated using the methods of Smibert \& Krieg (1994). Denitrification was determined according to the method of Dong \& Cai (2001).

Catalase activity was tested using the $3 \%(\mathrm{v} / \mathrm{v}) \mathrm{H}_{2} \mathrm{O}_{2}$ drop method with young cells grown on R2A agar. Oxidase activity was determined using a $1 \%$ solution of tetramethyl-p-phenylenediamine dihydrochloride. $\beta$-Galactosidase activity was tested by using the method of Gerhardt \& Krieg (1981). Utilization of substrates for growth was examined using basic medium [containing, $^{-1}$ distilled water: $1 \mathrm{~g}\left(\mathrm{NH}_{4}\right)_{2} \mathrm{HPO}_{4}, 0.3 \mathrm{~g} \mathrm{~K}_{2} \mathrm{HPO}_{4}$ and $0.05 \mathrm{~g}$ $\mathrm{MgSO}_{4} .7 \mathrm{H}_{2} \mathrm{O} ; \mathrm{pH}$ 7.2], supplemented with $0.02 \%(\mathrm{w} / \mathrm{v})$ yeast extract, various carbohydrates and alcohols at a concentration of $0.5 \%$, and organic acids and amino acids at $0.1 \%$. All results were recorded after incubation for 7 days. Differential physiological characteristics of strain $\mathrm{KS}-11^{\mathrm{T}}$ and the most related type strains of species of the genus Paracoccus are given in Table 1.

For pigment analysis, cells were grown on King's $\mathrm{B}$ and R2A agar. Determination of pigment production and spectral characteristics were performed by using extraction with methanol, according to Hildebrand et al. (1994), with a visible-UV LabTach UV-1000 spectrophotometer. Strain KS- $11^{\mathrm{T}}$ produced a water-insoluble yellow pigment with a major peak at $470 \mathrm{~nm}$; a fluorescent pigment was also detected.

For the determination of the phylogenetic position of strain $\mathrm{KS}-11^{\mathrm{T}}$, genomic DNA was extracted using the method of Marmur (1961) from cells cultured for 2 days in R2A liquid medium. The 16S rRNA gene was amplified using the bacterial universal primers 27F (5'-GAGAGTTTGATCCTGGCTCAG-3', Escherichia coli position 2746) and 1495R (5'-CTACGGCTACCTTGTTACGA-3', E. coli position 1476-1495). Based on the 16S rRNA sequence of strain KS- $11^{\mathrm{T}}$, a BLAST search showed that the strain was closely related to the genus Paracoccus. The identification of phylogenetic neighbours and calculation of pairwise $16 \mathrm{~S}$ rRNA gene sequence similarity were achieved using the EzTaxon server (http://www.eztaxon.org/; Chun et al., 2007). Strain KS $-11^{\mathrm{T}}$ showed the highest similarity with $P$. marinus NBRC $100637^{\mathrm{T}}$ (96.9\%), followed by P. koreensis KCTC $12238^{\mathrm{T}}$ (96.8\%), Paracoccus solventivorans KCTC $12190^{\mathrm{T}}(96.8 \%)$, Paracoccus alkenifer KCTC $12188^{\mathrm{T}}$ (96.2\%) and Paracoccus kocurii KCTC $12189^{\mathrm{T}}$ (95.8\%). The 16S rRNA gene sequences of related taxa were obtained from GenBank/EMBL/DDBJ databases. Multiple alignments were performed using the CLUSTAL $\mathrm{W}$ program

Table 1. Differential phenotypic characteristics of strain $\mathrm{KS}-11^{\top}$ and closely related species of the genus Paracoccus

Strains: $1, \mathrm{KS}-11^{\mathrm{T}}$ (P. chinensis sp. nov.; data from this study); 2, P. kocurii KCTC $12189^{\mathrm{T}}$ (Van Spanning et al., 2005); 3, P. alkenifer KCTC 12188 (Van Spanning et al., 2005); 4, P. solventivorans KCTC $12190^{\mathrm{T}}$ (Van Spanning et al., 2005); 5, P. koreensis KCTC 12238 ${ }^{\mathrm{T}}$ (La et al., 2005); 6, P. marinus NBRC $100637^{\mathrm{T}}$ (Khan et al., 2008). +, Positive; -, negative; NT, not tested.

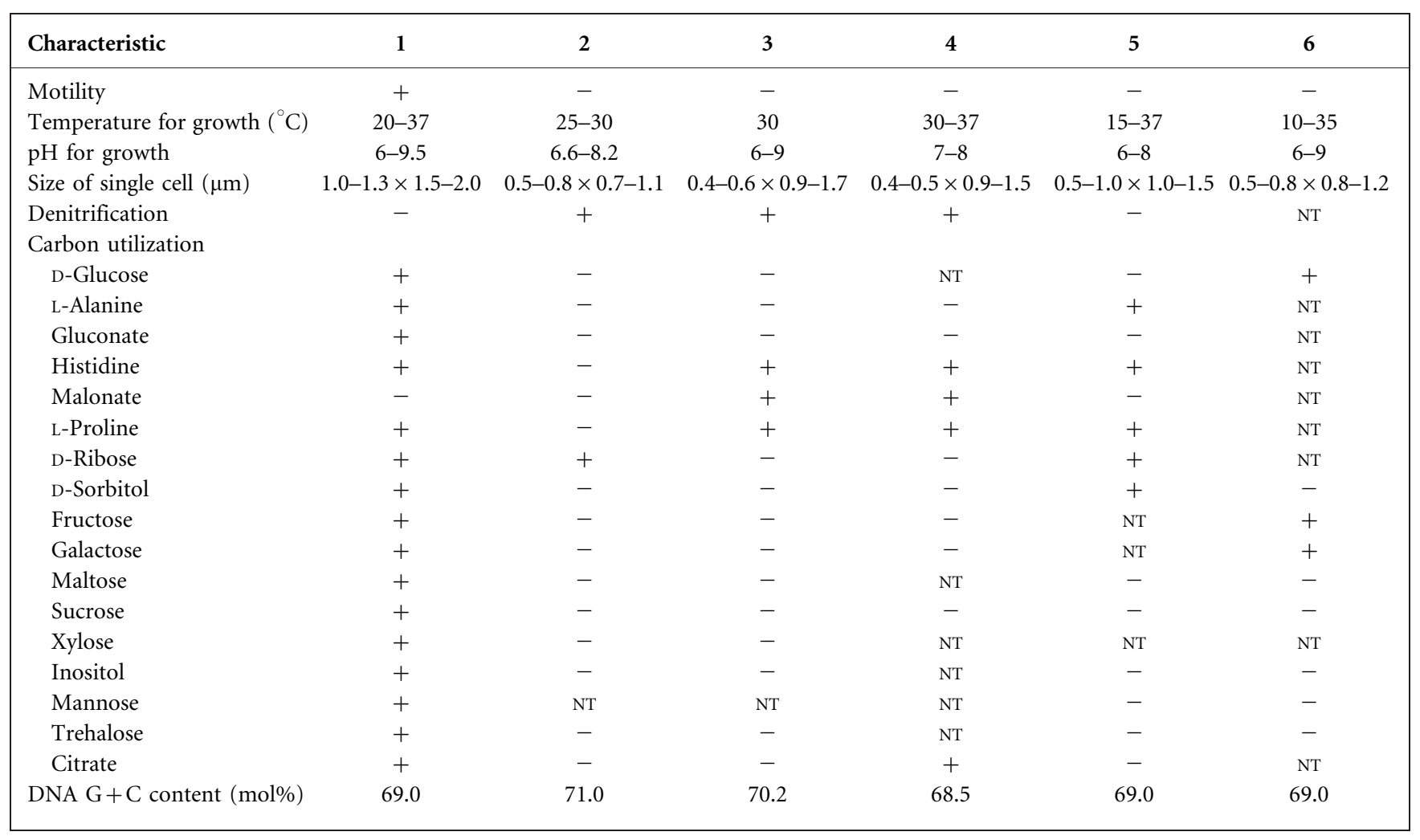


(Thompson et al., 1994). A phylogenetic tree was generated with the neighbour-joining method (Saitou \& Nei, 1987) using the MEGA 3.1 program (Kumar et al., 2004); the bootstrap values were evaluated based on 1000 replications (Felsenstein, 1985). Two other algorithms (minimumevolution and maximum-parsimony) were also used to construct phylogenetic trees. These showed similar topologies to that of the neighbour-joining tree (see Supplementary Fig. S1, available in IJSEM Online). The phylogenetic results indicated that strain KS- $11^{\mathrm{T}}$ belonged to the genus Paracoccus. The positions of strain KS- $11^{\mathrm{T}}$ and related species of the genus Paracoccus are shown in Fig. 1.

Analysis of cellular fatty acids was performed according to the protocol of the Sherlock Microbial Identification System (MIDI) with cells grown in R2A broth for 2 days. The fatty acids were analysed by gas chromatography (AGILENT 6890; Hewlett Packard) and identified using the Microbial Identification software package (Sasser, 1990). The fatty acid profile of strain KS- $11^{\mathrm{T}}$ comprised mainly $\mathrm{C}_{18: 1} \omega 7 \mathrm{c} / \omega 9 t / \omega 12 t$ (summed feature $7 ; 83.8 \%$ ), $\mathrm{C}_{18: 0}$ $(6.5 \%), \mathrm{C}_{16: 0}(2.9 \%)$ and $\mathrm{C}_{10: 0} 3-\mathrm{OH}(2.1 \%)$. Fatty acid profiles of strain $\mathrm{KS}-11^{\mathrm{T}}$ and the type strains of related recognized species are shown in Table 2 .

The $\mathrm{G}+\mathrm{C}$ content of the chromosomal DNA was determined by using the $T_{\mathrm{m}}$ method as described by De Ley (1970). The G $+C$ content of the genomic DNA of strain $\mathrm{KS}-11^{\mathrm{T}}$ was $69.0 \mathrm{~mol} \%$, within the range 63$71 \mathrm{~mol} \%$ for members of the genus Paracoccus (Harker et al., 1998).

Based on the data and observations given above, strain KS- $11^{\mathrm{T}}$ should be assigned to the genus Paracoccus as representing a novel species, for which the name Paracoccus chinensis sp. nov. is proposed.

\section{Description of Paracoccus chinensis sp. nov.}

Paracoccus chinensis (chi.nen'sis. N.L. masc. adj. chinensis pertaining to China, where the type strain was isolated and studied).

Cells are Gram-negative, aerobic, non-spore-forming, motile, ovoid- to coccus-shaped, $1.0 \times 1.3-1.5-2.0 \mu \mathrm{m}$ in size, and occur singly, in pairs, small clusters or short chains on R2A agar incubated for 3 days. Colonies on R2A agar are circular, smooth, moist, non-glossy, low-convex and colourless to orange. Growth occurs at $25-40{ }^{\circ} \mathrm{C}$ (optimum, $28-37{ }^{\circ} \mathrm{C}$ ), $\mathrm{pH}$ 6.0-9.5 (optimum, $\mathrm{pH}$ 7.5-9.0) and with less than $1 \% \mathrm{NaCl}$. Does not grow anaerobically using nitrate as electron acceptor. A water-insoluble yellow pigment is produced on R2A agar, with a major absorbance peak at $470 \mathrm{~nm}$. A fluorescent pigment is also produced at a low rate on King's B medium. Positive for catalase, oxidase, urease, lecithinase and hydrolysis of casein. Negative for arginine dihydrolase, $\beta$-galactosidase, lipase activity (Tween 80 ), production of indole and hydrogen sulfide, and hydrolysis of starch, gelatin and carboxymethylcellulose. Nitrate is reduced but not nitrite. Utilizes D-fructose, D-galactose, D-xylose, melibiose, melezitose, lactose, soluble starch, maltose, D-mannose, D-ribose, Lfucose, D-glucose, sucrose, D-sorbitol, inositol, salicin, inulin, gluconate, L-alanine, L-histidine, L-proline, Ltyrosine, L-asparagine, pyruvate, citrate and acetate, but not raffinose, D-arabinose, L-rhamnose, D-sorbose, Larabinose, malonate, mannitol, succinic acid, glycerol, lactate, succinate, L-glycine, L-cysteine, L-glutamic acid, methanol, ethanol or acetone. Major cellular fatty acids are $\mathrm{C}_{18: 1} \omega 7 c / \omega 9 t / \omega 12 t$ (summed feature 7 ) and $\mathrm{C}_{18: 0}$. The $\mathrm{G}+\mathrm{C}$ content of the genomic DNA of the type strain is $69.0 \mathrm{~mol} \%$.

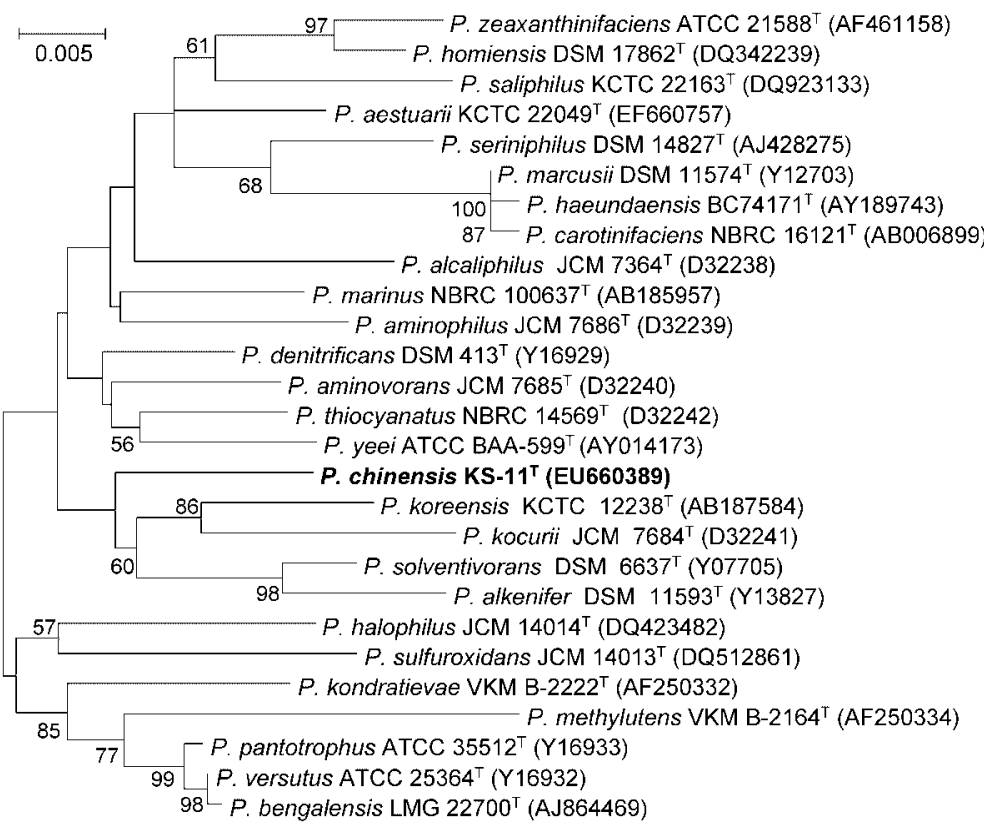

Fig. 1. Unrooted phylogenetic tree, showing the relationships of $P$. chinensis $\mathrm{KS}-11^{\top}$ and other related species. Bootstrap values (expressed as percentages of 1000 replications) greater than $50 \%$ are shown at branch points. Bar, 0.5 substitutions per $100 \mathrm{nt}$ positions. 
Table 2. Cellular fatty acid profiles (\%) of strain $\mathrm{KS}-11^{\top}$ and related type strains of Paracoccus species

Strains: $1, \mathrm{KS}-11^{\mathrm{T}}$ (P. chinensis sp. nov.; data from this study); $2, P$. kocurii KCTC $12189^{\mathrm{T}}$ (La et al., 2005); 3, P. alkenifer KCTC $12188^{\mathrm{T}}$ (La et al., 2005); 4, P. solventivorans KCTC $12190^{\mathrm{T}}$ (La et al., 2005); 5 , P. koreensis KCTC $12238^{\mathrm{T}}$ (La et al., 2005); 6, P. marinus NBRC $100637^{\mathrm{T}}$ and NBRC 100640 (Khan et al., 2008). tr, Trace amount $(<1 \%) ;-$, not detected.

\begin{tabular}{|lcccccc|}
\hline Fatty acid & $\mathbf{1}$ & $\mathbf{2}$ & $\mathbf{3}$ & $\mathbf{4}$ & $\mathbf{5}$ & $\mathbf{6}$ \\
\hline Saturated & & & & & & \\
$\mathrm{C}_{12: 0}$ & - & 1.1 & - & - & - & - \\
$\mathrm{C}_{13: 0}$ iso & $\operatorname{tr}$ & - & - & - & - & - \\
$\mathrm{C}_{13: 0}$ anteiso & 1.4 & - & - & - & - & - \\
$\mathrm{C}_{14: 0}$ & - & $\operatorname{tr}$ & - & - & - & - \\
$\mathrm{C}_{16: 0}$ & 2.9 & 4.0 & 1.6 & - & 2.3 & $\operatorname{tr}$ \\
$\mathrm{C}_{17: 0}$ & $\operatorname{tr}$ & 3.2 & 2.3 & 2.2 & - & $1-2$ \\
$\mathrm{C}_{18: 0}$ & 6.5 & 14.8 & 4.5 & 7.1 & 13.4 & $4-5$ \\
$\mathrm{C}_{19: 0}$ & - & 1.0 & 0.9 & - & - & $\operatorname{tr}$ \\
Unsaturated & & & & & & \\
$\mathrm{C}_{20: 1} \omega 9 t$ & - & 2.6 & 1.7 & 1.4 & - & - \\
$\mathrm{Hydroxy}^{2}$ & & & & & & \\
$\mathrm{C}_{16: 0} 2-\mathrm{OH}$ & - & 1.1 & - & - & - & - \\
$\mathrm{C}_{10: 0} 3-\mathrm{OH}$ & 2.1 & - & - & - & 2.4 & 2 \\
$\mathrm{C}_{19: 0}$ cyclo $\omega 8 \mathrm{c}$ & - & 34.5 & - & - & - & - \\
Summed features* & & & & & & \\
3 & - & $\operatorname{tr}$ & 2.3 & 3.2 & - & - \\
7 & 83.8 & 36.5 & 86.7 & 86.1 & 79.6 & $85-87$ \\
Unknown $\dagger$ & & & & & & \\
ECL 11.799 & 2.0 & - & - & - & - & 2.0 \\
& & & & & & \\
\hline
\end{tabular}

* Summed features are groups of two or three fatty acids that cannot be separated by GLC with the MIDI system. Summed feature 3 contains $\mathrm{C}_{14: 0} 3-\mathrm{OH}$ and/or $\mathrm{C}_{16: 1}$ iso $\mathrm{I}$; summed feature 7 contains $\mathrm{C}_{18: 1} \omega 7 c / \omega 9 t / \omega 12 t$.

†Unknown fatty acids have no name listed in the peak library file of the MIDI system and therefore cannot be identified. Equivalent chain-length (ECL) is given.

The type strain, KS- $11^{\mathrm{T}}$ (=CGMCC $1.7655^{\mathrm{T}}=\mathrm{NBRC}$ $104937^{\mathrm{T}}$ ), was isolated from sediment of the Guanting reservoir in China.

\section{Acknowledgements}

This work was supported by project no. 30670071 of the National Natural Science Foundation of China. It was also supported by the Special Program for water pollution control of Taihu Lake in Jiangsu Province (no. BK2007741).

\section{References}

Chun, J., Lee, J. H., Jung, Y., Kim, M., Kim, S., Kim, B. K. \& Lim, Y. W. (2007). EzTaxon: a web-based tool for the identification of prokaryotes based on $16 \mathrm{~S}$ ribosomal RNA gene sequences. Int J Syst Evol Microbiol 57, 2259-2261.
Davis, D. H., Doudoroff, M., Stanier, R. Y. \& Mandel, M. (1969). Proposal to reject the genus Hydrogenomonas: taxonomic implications. Int J Syst Bacteriol 19, 375-390.

De Ley, J. (1970). Reexamination of the association between melting point, buoyant density, and chemical base composition of deoxyribonucleic acid. J Bacteriol 101, 738-754.

Dong, X. Z. \& Cai, M. Y. (2001). Determinative Manual for Routine Bacteriology. Beijing: Scientific Press.

Felsenstein, J. (1985). Confidence limits on phylogenies: an approach using the bootstrap. Evolution 39, 783-791.

Gerhardt, P. \& Krieg, N. R. (1981). General characterization. In Manual of Methods for General Bacteriology, pp. 409-443. Edited by N. R. Krieg. Washington, DC: American Society for Microbiology.

Harker, M., Hirschberg, J. \& Oren, A. (1998). Paracoccus marcusii sp. nov., an orange Gram-negative coccus. Int J Syst Bacteriol 48, 543-548.

Hildebrand, D. C., Palleroni, N. J., Hendson, M., Toth, J. \& Johnson, J. L. (1994). Pseudomonas flavescens sp. nov., isolated from walnut blight cankers. Int J Syst Bacteriol 44, 410-415.

Khan, S. T., Takaichi, S. \& Harayama, S. (2008). Paracoccus marinus sp. nov., an adonixanthin diglucoside-producing bacterium isolated from coastal seawater in Tokyo Bay. Int J Syst Evol Microbiol 58, 383-386.

Kim, B. Y., Weon, H. Y. \& Yoo, S. H. (2006). Paracoccus homiensis sp. nov., isolated from a sea-sand sample. Int J Syst Evol Microbiol 56, 2387-2390.

Kumar, S., Tamura, K. \& Nei, M. (2004). MEGA3: integrated software for Molecular Evolutionary Genetics Analysis and sequence alignment. Brief Bioinform 5, 150-163.

La, H. J., Im, W. T., Ten, L. N., Kang, M. S., Shin, D. Y. \& Lee, S. T. (2005). Paracoccus koreensis sp. nov., isolated from anaerobic granules in an upflow anaerobic sludgeblanket (UASB) reactor. Int J Syst Evol Microbiol 55, 1657-1660.

Liu, Z. P., Wang, B. J., Liu, X. Y., Dai, X., Liu, Y. H. \& Liu, S. J. (2008). Paracoccus halophilus sp. nov., isolated from marine sediment of the South China Sea, China, and emended description of genus Paracoccus Davis 1969. Int J Syst Evol Microbiol 58, 257-261.

Marmur, J. (1961). A procedure for the isolation of deoxyribonucleic acid from microorganisms. J Mol Biol 3, 208-218.

Qu, J. H. \& Yuan, H. L. (2008a). Sediminibacterium salmoneum gen. nov., sp. nov., a novel member of the phylum Bacteroidetes isolated from sediment of a eutrophic reservoir. Int J Syst Evol Microbiol 58, 2191-2194.

Qu, J. H., Li, H. F., Yang, J. S. \& Yuan, H. L. (2008b). Flavobacterium cheniae sp. nov., isolated from sediment of a eutrophic reservoir. Int $J$ Syst Evol Microbiol 58, 2186-2190.

Rainey, F. A., Kelly, D. P., Stackbrandt, E., Burghardt, J., Hiraishi, A., Katayama, Y. \& Wood, A. (1999). A re-evaluation of the taxonomy of Paracoccus denitrificans and a proposal for the combination Paracoccus pantotrophus comb. nov. Int J Syst Bacteriol 49, 645-651.

Saitou, N. \& Nei, M. (1987). The neighbor-joining method: a new method for reconstructing phylogenetic trees. Mol Biol Evol 4, 406-425.

Sasser, M. (1990). Identification of bacteria by gas chromatography of cellular fatty acids, MIDI Technical Note 101. Newark, DE: MIDI Inc.

Siller, H., Fred, A. R., Stackebrandt, E. \& Winter, J. (1996). Isolation and characterization of a new Gram-negative, acetone-degrading, nitrate-reducing bacterium from soil, Paracoccus solventivorans sp. nov. Int J Syst Bacteriol 46, 1125-1130.

Skerman, V. B. D. (1967). A Guide to the Identification of the Genera of Bacteria, 2nd edn. Baltimore: Williams \& Wilkins.

Smibert, R. M. \& Krieg, N. R. (1994). Phenotypic characterization. In Methods for General and Molecular Bacteriology, pp. 607-654. Edited 
by P. Gerhardt, R. G. E. Murray, W. A. Wood \& N. R. Krieg. Washington, DC: American Society for Microbiology.

Thompson, J. D., Higgins, D. G. \& Gibson, T. J. (1994). CLUSTAL $\mathrm{W}$ : improving the sensitivity of progressive multiple sequence alignment through sequence weighting, position-specific gap penalties and weight matrix choice. Nucleic Acids Res 22, 46734680.

Urakami, T., Araki, H., Oyanagi, H., Suzuki, K. \& Komagata, K. (1990). Paracoccus aminophilus sp. nov. and Paracoccus aminovorans sp. nov., which utilize $\mathrm{N}, \mathrm{N}$-dimethylformamide. Int J Syst Bacteriol 40, 287-291.

Van Spanning, R. J. M., Stouthamer, A. H., Baker, S. C. \& Van Verseveld, H. W. (2005). Genus XII. Paracoccus Davis 1969, $384^{\mathrm{AL}}$ emend. Ludwig, Mittenhuber and Friedrich 1993, 366. In Bergey's Manual of Systematic Bacteriology, 2nd edn, vol. 2 (The Proteobacteria), part C (The Alpha-, Beta-, Delta-, and Epsilonproteobacteria), pp. 197204. Edited by D. J. Brenner, N. R. Krieg, J. T. Staley \& G. M. Garrity. New York: Springer. 